J. Perinat. Med. 3 (1975) 161

\title{
Maternal and fetal plasma levels of free corticosteroids during normal delivery
}

\author{
Joseph Schmid, Ulrich Briner \\ Deparment of Gynecology and Obstetrics, University of Zurich, Switzerland \\ (Chairman: Prof. Dr. W. E. Schreiner)
}

Received: November 6, 1974. Accepted: February 11, 1975.

An increase in the concentration of free corticosteroids, especially of cortisol, with increasing gestational age in the maternal plasma $[4,5,6$, $9,11]$ and in the umbilical vessels $[4,11,18,19]$ as well as in the maternal plasma during delivery $[3,4,5,13]$ is well known. The influence of placental diffusion and of the fetal adrenal cortex have been studied in detail $[1,2,11,12,14]$. While some authors $[4,8]$ have demonstrated a correlation between fetal plasma corticosteroid values and maternal plasma concentrations, other investigators have denied this correlation $[5,7]$. Differences in the methodology and a varying selection of the material for investigation have lead to great discrepancies in the results.

This paper will deal with the changes of free corticosteroids in fetal and maternal plasma during normal vaginal deliveries. Total corticosteroids were determined which after plasma extraction are bound to corticosteroid bindingglobulin ( $\mathrm{CBG}=$ transcortin).

\section{Material and methods}

The investigations were carried out in patients and their children fulfilling the following criteria: pregnancies without complications, normal births with spontaneous delivery from occiput anterior position, delivery between the 38th and 40th weeks of gestation, one minute Apgar score greater than 8 . The blood samples of mother and fetus were obtained during the various stages of delivery: early first stage (Cervix dilatation

\section{Curriculum vitae}

Josepr SCHMid, Study of medicine in Paris, Wien and Zurich.

Following graduation from 1961-1963 Surgical Department of the University of Zurich. Since 1964 at University Gynecological Clinic of Zuricls. University lecturer 1969 and since 1972 cbief resident (1. Oberarzt).

Main research interests: the

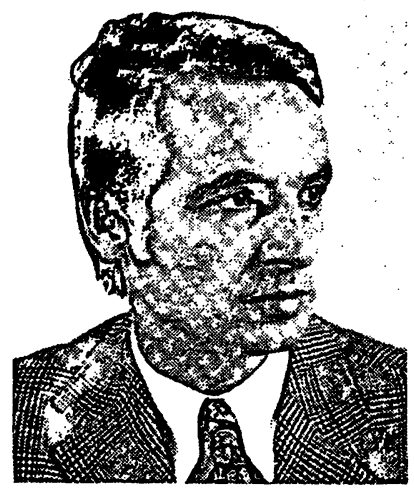

fetal metabolism during labor and the surveillance of the intrauterine fetus.

1-6 cm: EP 1), late first stage (Cervix dilatation $6-10 \mathrm{~cm}$ : EP 2), second stage of labor (cervix dilatation complete, presenting part on the pelvic floor: AP), during delivery and in the newborn infants 60 and 120 minutes after birth. The blood was drawn in mothers and infants from the anticubital vein. Fetal blood was obtained from the hyperemic scalp according to the method described by SALING [17] and immediately after birth from a proximally and distally clamped segment of the umbilical cord.

Duplicate determinations of free corticosteroids were performed according to the method described by MuRPHY [10], a protein binding assay with CBG. The corticosteroids were extracted from plasma with ethanol. $98 \%$ pure cortisol served as standard; $1,2,{ }^{3} \mathrm{H}$ cortisol served as tracer. Pooled normal human plasma from which 
endogenous free corticosteroids had been absorbed was the source of CBG. The results were read from a standard curve as cortisol equivalents. The accuracy of single values was checked against the calculated reproducability from 96 double determinations; it was $8.6 \mu \mathrm{g} / 100 \mathrm{ml}(\dot{p}<0.05)$. Corticosteroids extracted from plasma were not fractionated further by precipitation or chromatography. All corticosteroids contained in the ethanol fraction were thus determined. A crossreaction on the $\mathrm{CBG}$ occurs principally with corticosterone $(100 \%)$, progesteron $(20-40 \%)$ and cortisone $(10 \%)$. While most steroids except cortisol and cortisone are quantatively insignificant, progesteron raises during pregnancy and at term it may displace $30 \%$ of cortisone found to $C B G$ [15]. Therefore, our values are inpart considerably higher than cortisol concentrations reported by other authors. However, since the plasma progesteron concentration during the delivery changes little [16], it may be assumed that the increase of corticosteroids during delivery is principally due to an increase in 17-hydroxyketosteroids.

\section{Results}

In the fetus (Tab. I) plasma corticosteroid values at the beginning of the first stage have a mean of $34 \mu \mathrm{g} / 100 \mathrm{ml}$. Until birth there is a continuous increase to $42 \mu \mathrm{g} / 100 \mathrm{ml}$ in the umbilical artery. The increase of $8 \mu \mathrm{g} / 100 \mathrm{ml}$ is significant at $\mathrm{p}<0.025$. The arterial-venous difference of $15 \mu \mathrm{g} / 100 \mathrm{ml}$ is highly significant at $p<0.001$. After the first hours after birth there is significant decrease in the plasma corticosteroid concentration. Afterwards the newborn has values equivalent to those at the beginning of labor.

In mothers too, there was an increase from $56 \mu \mathrm{g} / 100 \mathrm{ml}$ to $68 \mu \mathrm{g} / 100 \mathrm{ml}$ (Tab. II); the mean difference of $12 \mu \mathrm{g} / 100 \mathrm{ml}$ is significant $(p<0.005)$. However, the increase is not gradual as in the fetus, but only at the moment of birth. The difference between maternal values at the time of birth and the umbilical vein was $11 \mu \mathrm{g} / 100 \mathrm{ml}$ and that between mother and umbilical artery was $26 \mu \mathrm{g} / 100^{\prime} \mathrm{ml}$. Both differences are significant.
Tab. I. Plasma concentration of free corticosteroids in fetal scalp blood during different stages of delivery, at birth (umbilical artery and vein) and 60 and 120 minutes after birth in the newborn in $\mu \mathrm{g} / 100 \mathrm{ml}$.

$\mathrm{EP} 1=$ cervix $1-5 \mathrm{~cm} ; \mathrm{EP} 2=$ cervix $6-10 \mathrm{~cm} ; \mathrm{AP}=$ cervix complete, descending part on pelvic floor: $\mathrm{n}=$ number of cases.

$\pm \mathrm{S}=$ standard deviation of the mean $(\overline{\mathrm{x}})$

$2 \mathrm{p}=$ confidence limits

$\left.\begin{array}{lccccc}\hline \text { Fetus - Infant } & \mathrm{n} & \overline{\mathbf{x}} & \pm \mathrm{S} & \multicolumn{2}{c}{\text { 2p }} \\ \hline \text { EP 1 } & 25 & 34 & 10 & \text { ns } \\ \text { EP 2 } & 10 & 37 & 11 & \text { ns } \\ \text { AP } & 10 & 40 & 9 & \text { ns }\end{array}\right\}<0.025$

Tab. II. Plasma concentration of free corticosteroids in maternal venous blood during the different stages of labor (Legend as in Tab. I).

$\left.\begin{array}{lcccc}\hline \multicolumn{1}{r}{\text { Mother }} & \mathrm{n} & \overline{\mathbf{x}} & \pm \mathrm{S} & 2 \mathrm{p} \\ \hline \text { EP 1 } & 28 & 56 & 13 & \text { ns } \\ \text { EP 2 } & 10 & 59 & 13 & \text { ns } \\ \text { AP } & 15 & 53 & 12 & <0.001\end{array}\right\}<0.005$

\section{Discussion}

Plasma concentration of corticosteroids found in the literature show considerable variation. This is in part caused by different methods of assay, extraction and fractionation as well as by the selection of patients and the source and timing of blood samples. We were able to confirm the known increase $[5,13]$ of free corticosteroids in maternal plasma during birth. With the aid of micro-blood determinations we were also successful in demonstrating a continuous increase in fetal plasma. In contrast our result showed only little change in the maternal plasma corticosteroid concentrations during the first stage of labor. However, during the second stage there is a marked increase until birth. Similar results were obtained by JoLIVET et al. [5].

In a comparable experimental design Murphy and DIEZ D'Aux [11] determined a corticosteroid concentration of $77.0 \pm 4.0 \mu \mathrm{g} / 100 \mathrm{ml}$ in the venous blood of mothers of male newborns. 
Our values of $68.0 \mu \mathrm{g} / 100 \mathrm{ml}$ are somewhat lower.

Larger discrepancies have been reported for corticosteroid levels in the umbilical cord. The fact that most authors $[4,6,7,8,11]$ used pooled umbilical cord blood makes a comparison with our results difficult. Considerably higher values were found by KRAUER [7] while other authors $[4,11,18]$ gave somewhat lower values. An arterial-venous gradient with higher corticosteroid concentration in the umbilical vein was found also by SMIth and Shearman $[18,19]$. On the other hand, CAwson and co-workers [3] found no significant difference of various 17hydroxy-corticosteroids in the umbilical vessels. The higher corticosteroid concentrations in the umbilical artery might be explained by placental transfer or increased maternal plasma concentration during delivery. In addition, it must be taken into account that we did not remove progesteron from our extracts which binds competatively to CBG which also shows a higher concentration in the umbilical vein than in the artery [16].

The elevated concentration of free corticosteroids in the umbilical cord blood has been interpreted differently. Gemzell [4] found a constant ratio between the concentration of 17-OH-corticosteroids in the maternal and umbilical blood and assumed that the fetal plasma concentration effected only the conditions in the mother. Migeon et al. [8] postulated a selected placental barrier for $17-\mathrm{OH}$-corticosteroid but no or only minimal fetal production. In contrast MURPHY

\section{Summary}

The variation of the concentration of free corticosteroids in maternal and fetal plasma during labor have been measured. The mothers had to fulfill the following conditions: Gestation without complications and undisturbed delivery at term in anterior occipital position. The Apgar score should not be less than 8 after 1 minute. Blood was collected at fixed time-intervals, from the cubital vein of mothers and neonates and from the scalp of the fetuses. In the umbilical vessels blood was collected separately by punction from the veins and arteries. A competitive protein-binding assay with corticosteroid-binding globulin (CBG) served for the measurement of total free corticosteroids. After extraction with ethanol and binding to $\mathrm{CBG}$ the corticosteroids were measured as equivalents of a cortisol-standard. and Diez D'Aux [11] believe that the increase of corticosteroids in the umbilical artery is caused by an increased fetal production. Beirins et al. [2] investigated in sheep the placental passage of cortisols. They used differentially labeled cortisol, which was injected in the maternal and fetal circulation. Thus they could demonstrate that fetal corticosteroid passes pratically without limit the placenta while a transfer from the mother to the fetus is apparently limited. Our results demonstrate a significant gradient for free corticosteroids between mother and fetus. Even more marked are the differences for pure cortisol $[3,5,11,14]$. Parallel to the increasing corticosteroid production of the mother during pregnancy there is an increase in steroid synthesis by the fetal adrenal cortex [11]. During the stress of delivery the steroids rise further [14, 19]. Future investigation will deal with the questions whether varying modes of delivery with a varying stress on mother and fetus is responsible for the differences in the corticosteroid levels in the umbilical cord plasma $[3,7,14,19]$ or whether other factors come into play. In spite of the function of the placenta as a barrier against the transfer of maternal corticosteroids into the fetal circulation we demonstrated in the fetal scalp blood a significant increase of free corticosteroids during delivery before this could be observed in the mother. Consequently we conclude that an important contribution to this increase is made by the fetal adrenal cortex.

There was a significant rise of free corticosteroids in the fetal plasma from $34 \pm 10$ to $42 \pm 9 \mu \mathrm{g} / 100 \mathrm{ml}$. After delivery a rapid fall to values of the early dilatation phase took place (Tab. I). Only in the moment of delivery we found a rise in the maternal plasma from $56 \pm 13$ to $68 \pm 14$. This was also significant (Tab. II). In the umbilical vessels the mean difference in arterial and venous plasma-concentration of corticosteroids is $15 \mu \mathrm{g} /$ $100 \mathrm{ml}$, a proportion of almost $3: 2$.

Though the concentration of free corticosteroids in maternal and fetal plasma increases during labor, the fetus does not simply reflect the maternal situation. A substantial contribution of the fetal adrenal gland to the fetal plasmacorticosteroids may be supposed. 
Keywords: Adrenal gland, corticosteroids, delivery, fetus, newborn, placental transfer.

\section{Zusammenfassung}

Mütterlicher und fetaler Plasmaspiegel der freien Kortikosteroide während der normalen Geburt

Die Veränderung der freien Kortikosteroidkonzentration sub partu wurde im mütterlichen und fetalen Plasma eines Normalkollektivs unter der Geburt bestimmt. Die Patientinnen mußten folgende Bedingungen erfüllen: Komplikationsloser Schwangerschaftsverlauf mit Spontangeburt am Termin aus vorderer Hinterhauptslage. Bei den Neugeborenen betrug die ApgAR-Ziffer nach 1 Minute 8 und mehr. Die Blutentnahmen erfolgten $\mathrm{zu}$ festgesetzten Zeitintervallen, bei der Mutter und beim Neugeborenen aus der Kubitalvene, beim Feten durch Mikroblutuntersuchung aus dem Kopfschwartenblut. Blut aus den Nabelgefäßen wurde durch separate Punktion der Venen und Arterien erhalten. Als Bestimmungsmethode diente ein competitive protein-binding assay mit corticosteroid-binding globulin (CBG). Nach Äthanol-Extraktion aus dem Plasma wurden die an CBG bindenden Kortikosteroide gemessen als Äquivalente eines Kortisol-Standards. i

Die fetalen Kortikosteroide stiegen unter der Geburt signifikant an, von $34 \pm 10 \mu \mathrm{g} / 100 \mathrm{ml}$ auf $42 \pm 9 \mu \mathrm{g} /$ $100 \mathrm{ml}$, fielen dann innerhalb 2 Stunden post partum wieder auf den Ausgangswert ab (Tab. I). Die Zunahme im mütterlichen Plasma erfolgte erst im Zeitpunkt der Austreibung, von $56 \pm 13$ auf $68 \pm 14 \mu \mathrm{g} /$ $100 \mathrm{ml}$ (Tab. II). Sie ist ebenfalls signifikant. In den Nabelgefäßen fand sich ein durchschnittlicher Konzentrationsunterschied von $15 \mu \mathrm{g} / 100 \mathrm{ml}$ zwischen Nabelvene und Nabelarterie, was einem Verhälnnis von beinahe 3:2 entspricht.

Obwohl die Plasmakonzentration der freien Kortikosteroide unter der Geburt bei Mutter und Fet ansteigt, werden beim Feten nicht einfach die mütterlichen Verhältnisse widerspiegelt. Es ist anzunehmen, daß die fetale Nebenniere einen wesentlichen Beitrag an die Kortikosteruidkonzentration des fetalen Plasmas leistet.

Schlüsselworte: Fet, Kortikosteroide, Neugeborenes, Nebenniere, Plazentapassage.

Résumé

Taux des corticostéroides libres dans le plasma maternel et foetal au cours d'un accouchement normal

Le présent article traite de l'analyse de l'altération de la concentration des corticostéroides libres sub partu dans le plasma maternel et foetal d'un groupe collectif en cours d'accouchement. Les patientes devaient remplir les conditions suivantes: grossesse sans complication avec accouchement spontané à la date prévue avec position antérieure du bregma. Chez les nouveaux-nés, le chiffre Apgar était de 8 et plus après une minute. Les prises de sang ont été effectuées à intervalles déterminés, dans la veine cubitale chez la mère et le nouveau-né et par examen microsanguin du cuir chevelu chez le foetus. Le sang des vaisseaux ombilicaux a été obtenu par ponction séparée des veines et des artères. Comme méthode d'estimation, on s'est servi d'un "competitive protein-binding assay» avec «corticosteroid-binding globulin» (CBG). Après extraction à l'éthanol du plasma, les corticostéroides liés à la $C B G$ ont été mesurés comme équivalents d'un standard cortisol.
Les corticostéroides foetaux ont augmenté de façon significative durant l'accouchement, de $34 \pm 10 \mu \mathrm{g} /$ $100 \mathrm{ml}$ à $42 \pm 9 \mu \mathrm{g} / 100 \mathrm{ml}$, pour retomber en l'espace de deux heures post partum à leur niveau initial (Tab. I). La hausse dans le plasma maternel, tout aussi significative, ne s'est produite qu'au moment de l'expulsion, de $56 \pm 13$ à $68 \pm 14 \mu \mathrm{g} / 100 \mathrm{ml}$ (Tab. II). On a observé dans les vaisseaux ombilicaux une diffèrence de concentration moyenne de $15 \mu \mathrm{g} / 100 \mathrm{ml}$ entre la veine ombilicale et l'artère ombilicale, ce qui correspond à un rapport de près de 3:2.

Bien que la plasmaconcentration des corticustéroides libres augmente chez la mère et 'le foetus en cours $d$ ' accouchement, les conditions proportionnelles maternelles ne se reflètent pas exactement chez le foetus, ce qui fait supposer que la capsule surrénale foetale contribue de façon substantielle à la concentration des corticostéroides du plasma foetal.

Mots-clés: Capsule surrénale, corticostéroides, foetus, nouveau-né, passage placentaire.

\section{Acknowledgement}

This work was supported by grants from the Schweizerischen Nationalfonds zur Förderung der wissenschaftlichen Forschung Nr. 3662.

\section{Bibliography}

[1] Alexander, D. P., H. G. Britton, V. H. T. James, D. A. Nixon, M. A. Parker, M. Wintour, R. D.
WRIGHT: Steroid secretion by the adrenal gland of fetal and neonatal sheep. J. Endocrin. 40 (1968) 1 
[2] Bertins, J. Z., A. Kowarski, D. W. Shermeta, R. A. De Lemos, C. J. Migeon: Fetal and maternal secretion rate of cortisol in sheep: Diffusion resistance of the placenta. Pediat. Res. 4 (1970) 129

[3] Cawson, M. J., A. B. M. Anderson, A. L. Turnbull, I. Lampe: Cortisol, Cortisone, and 11-Deoxycortisol levels in human umbilical and maternal plasma in relation to the onset of labor. J. Obstet. Gynec. Brit. Cwlth. 81 (1974) 737

[4] Gemzell, C. A.: Variations in plasma levels of 17$\mathrm{OH}$-corticostcroids in mother and infant during and after pregnancy. Acta Endocrin. 17 (1957) 100

[5] Jolivet, A., H. Blanchier, J. P. Gautray, N. Dhem: Blood cortisol variations during late pregnancy and labor. Amer. J. Obstet. Gynec. 119 (1974) 775

[6] Keller, P. J.: Pregnancy. In: Labhardt, A.: Clinical Endocrinology. Springer, Berlin-Heidelberg-New York, 1974

[7] Krauer, F.: Maternal and umbilical cord plasmacortisolconcentrations related to different types of deliveries. Arch. Gynäk. 215 (1973) 343

[8] Migeon, C. J., H. Prystowsky, M. M. Grumbach, M. C. Byron: Placental passage of 17-OH-corticosteroids: Comparison of the levels in maternal and fetal plasma and effect of ACTH and Hydrocortisone administration. J. clin. Invest. 35 (1956) 488

[9] Mukherjee, K.: Plasma cortisol and ACTH in normal men and non pregnant women, normal pregnant women and women with preeclampsia. J. Obstet. Gynaec. Brit. Cwlth. 79 (1972) 504

[10] Murphy, B. E. P.: Some studies of the proteinbinding of steroids and their application to the routine ultramicro measurements of various steroids in body fluids be competitive protein-binding radioassay. J. clin. Endocrin. 27 (1967) 973
[11] Murphy, P. B. E., R. C. Diez D'Aux: Steroid levels in the human fetus: Cortisol and cortisone. J. clin. Endocrin. Metab. 35 (1972) 678

[12] Murphy, P. B. E.: Does the human fetal adrenal play a role in parturition? Amer. J. Obstet. Gynec. 115 (1973) 521

[13] Okada, D. M., D. Tulchinsky, J. W. Ross, C. J. Hoвe: Plasma estrone, estradiol, estriol, progesteron and cortisol in normal labor. Amer. J. Obstet. Gynec. 119 (1974) 902

[14] Poкоly, I. B.: The role of cortisol in human parturition. Amer. J. Obstet. Gynec. 117 (1973) 549

[15] Rosenthal, H. E., W. R. Slaunwhite, A. A. SandBERG: Transcortin: A corticosteroid binding protein of the plasma. X: Cortisol and progesterone interplay and unbound levels of these steroids in pregnancy. J. clin. Endocrin. 29 (1969) 352

[16] Runnebaum, B., J. Zander: Progesteron, $44-$ Pregnen - 20 $\alpha$-ol-3-on, 44 -Pregnen - 20 $\beta$-ol-3-on und 17 $\alpha$-Hydroxyprogesteron der Nabelvenen und Nabelarterien. Klin. Wschr. 40 (1962) 453

[17] Saling, E.: Neue Untersuchungsmöglichkeiten des Kindes unter der Geburt (Einführung und Grundlagen). Zbl. Gynäk. 83 (1961) 1906

[18] Smith, J. D., R. P. Shearman: Fetal plasma steroids in relation to parturition: I The effect of gestational age upon umbilical plasma corticosteroid levels following vaginal delivery. J. Obstet. Gynaec. Brit. Cwlth. 81 (1974) 11

[19] Smith, J. D., R. P. Shearman: Fetal plasma steroids in relation to parturition: II The effect of gestational age upon umbilical plasma corticosteroids following hysterotomy and caesarean section. J. Obstet. Gynec. Brit. Cwlth. 81 (1974) 16
Dr. J. Schmid

1. Oberarzt

Univ.-Frauenklinik

CH-8006 Zürich 